\title{
Ionotropic receptors at hippocampal mossy fibers: roles in axonal excitability, synaptic transmission, and plasticity
}

\author{
Arnaud J. Ruiz ${ }^{1 *}$ and Dimitri M. Kullmann ${ }^{2 *}$ \\ Department of Pharmacology, UCL School of Pharmacy, London, UK \\ 2 Department of Clinical and Experimental Epilepsy, UCL Institute of Neurology, London, UK
}

\author{
Edited by: \\ Peter Jonas, Institute of Science \\ and Technology Austria, Austria \\ Reviewed by: \\ Nicholas P. Vyleta, Institute of \\ Science and Technology Austria, \\ Austria \\ Josef Bischofberger, University \\ of Basel, Switzerland \\ ${ }^{*}$ Correspondence: \\ Arnaud J. Ruiz, Department \\ of Pharmacology, UCL School of \\ Pharmacy, Brunswick Square, \\ London WC1N 1AX, UK. \\ e-mail: a.ruiz@ucl.ac.uk \\ Dimitri M. Kullmann, Department of \\ Clinical and Experimental Epilepsy, \\ UCL Institute of Neurology, Queen \\ Square, London WC1N 3BG, UK. \\ e-mail:d.kullmann@ucl.ac.uk
}

Dentate granule cells process information from the enthorinal cortex en route to the hippocampus proper. These neurons have a very negative resting membrane potential and are relatively silent in the slice preparation. They are also subject to strong feed-forward inhibition. Their unmyelinated axon or mossy fiber ramifies extensively in the hilus and projects to stratum lucidum where it makes giant en-passant boutons with CA3 pyramidal neurons. There is compelling evidence that mossy fiber boutons express presynaptic $\mathrm{GABA}_{A}$ receptors, which are commonly found in granule cell dendrites. There is also suggestive evidence for the presence of other ionotropic receptors, including glycine, NMDA, and kainate receptors, in mossy fiber boutons. These presynaptic receptors have been proposed to lead to mossy fiber membrane depolarization. How this phenomenon alters the excitability of synaptic boutons, the shape of presynaptic action potentials, $\mathrm{Ca}^{2+}$ influx and neurotransmitter release has remained elusive, but high-resolution live imaging of individual varicosities and direct patch-clamp recordings have begun to shed light on these phenomena. Presynaptic $\mathrm{GABA}_{A}$ and kainate receptors have also been reported to facilitate the induction of long-term potentiation at mossy fiber-CA3 synapses. Although mossy fibers are highly specialized, some of the principles emerging at this connection may apply elsewhere in the CNS.

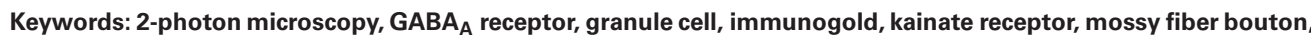
NMDA receptor, single channel
}

\section{INTRODUCTION}

There are approximately one million granule cells within the rat dentate gyrus, all projecting a thin unmyelinated axon that forms a single parent fiber in stratum lucidum, where it makes synaptic contacts onto CA3 pyramidal cells and various types of interneurones (Amaral et al., 1990; Acsady et al., 1998). These unusual axons (or mossy fibers) provide one of the most powerful glutamatergic input in the brain amid the low basal firing rate observed in granule cells in vivo $(<0.5 \mathrm{~Hz})$ and the inability of granule cells to fire action potentials for extended periods of time (Jung and McNaughton, 1993). Mossy fiber-CA3 synapses express a unique form of frequency-dependent facilitation of transmitter release that has a pronounced effect with only modest increases in presynaptic firing frequency (Salin et al., 1996), hence driving CA3 network activity very efficiently (Wiebe and Staubli, 1999; Henze et al., 2002). In addition, mossy fiber-CA3 synapses express presynaptic forms of long-term plasticity (LTP and LTD) that are expressed by persistent changes in the probability of glutamate release (Nicoll and Schmitz, 2005).

It is now emerging that many of these physiological processes are regulated by ionotropic receptors localized in presynaptic and perisynaptic membranes in mossy fibers themselves. In this paper, we discuss recent advances in our understanding of presynaptic receptor function at hippocampal mossy fiber synapses and expand on the view that they act as important modulators of synaptic transmission and plasticity in CA3 targets. We first introduce some of the techniques that have been employed to investigate presynaptic ionotropic receptors at mossy fibers. We then review the evidence showing the types of ionotropic receptors and the potential sources of neurotransmitters that can activate them, the downstream signaling mechanisms that ensue, and the differing forms of synaptic plasticity mediated by these receptors at synapses formed onto CA3 pyramidal neurons.

Several criteria must be met to unambiguously identify presynaptic ionotropic receptors in axon terminals. These include (1) ultrastructural localization of a particular receptor subunit to the presynaptic membrane, (2) detection of single channel activity in an excised patch from the presynaptic membrane; (3) evidence that exogenous activation of the receptor affects the presynaptic membrane potential or resistance. Moreover, (4) to argue that the receptor has a physiological role, it is necessary to show that it can be activated by the endogenous neurotransmitter upon activation of appropriate axons, and that this can be blocked or modulated by selective ligands.

\section{METHODS AVAILABLE TO INVESTIGATE PRESYNAPTIC RECEPTOR FUNCTION}

Among the plethora of experimental approaches available for measuring changes in axonal excitability and release probability consecutive to receptor activation, only high-resolution imaging 
and presynaptic recordings allow direct access to the presynaptic compartment (Figure 1). All other methods that rely on electrophysiology and statistical analysis (miniature synaptic current frequency analysis, CV analysis and paired-pulse ratio of amplitude of electrically-evoked responses) can only yield indirect estimates and suffer serious drawbacks since the recordings are being made either from postsynaptic targets, the somatic compartment, or the extracellular space.

Briefly, when recording from postsynaptic cells, activation of the presynaptic receptor should affect the frequency of miniature synaptic currents in preference to their amplitudes, and the paired-pulse ratio of two consecutively evoked synaptic currents should be increased or decreased by presynaptic receptor activation (Zucker et al., 1998). However, using the paired-pulse ratio as a sole indicator of presynaptic receptor activation should be made with caution since postsynaptic mechanisms can also contribute (Kirischuk et al., 2002), and an autoreceptor function can also occlude the change in paired-pulse ratio expected of a presynaptic modulation. A complementary analysis is to compare the $\mathrm{CV}$ with the mean amplitude of evoked synaptic currents to deduce whether variation in synaptic efficacy has a presynaptic or postsynaptic locus. Generally, proportionate changes in $\mathrm{CV}^{-2}$ and mean amplitude imply presynaptic modulation of transmitter release, whereas changes to the mean amplitude without change in $\mathrm{CV}^{-2}$ imply modulation of postsynaptic receptors (Edwards et al., 1989; Manabe et al., 1993). However, further complications arise from this kind of analysis when considering other parameters that can influence baseline receptor occupancy and diffusion and uptake of neurotransmitters, such as the recording temperature (Rusakov and Kullmann, 1998; Perrais and Ropert, 1999).

Several other electrophysiological techniques can be deployed to investigate the effect of receptor activation on axonal excitability (Wall, 1958), the vast majority of which makes use of extracellular electrical stimulation combined with single axon unit recordings or recordings of the compound presynaptic action potential (the afferent volley). These methods often lack spatial resolution and can be sensitive to drift, hampering the analysis of the effect of receptor activation on single fiber threshold. They are also extremely sensitive to ionic shifts in the extracellular space, in particular to $\mathrm{K}^{+}$that tends to accumulate during repetitive activity and can alter fiber threshold.

An alternative method to measure changes in fiber excitability is to record antidromic action potentials evoked via a stimulus electrode positioned in the axonal projection zone. In the voltageclamp configuration, these are detected as action currents. Two approaches have been taken to examine changes in the probability for evoking antidromic action currents consecutive to receptor modulation. In its most simple implementation, a thresholdstraddling stimulus is applied so that the success rate for evoking antidromic action currents is set to $\sim 50 \%$. Local application of drugs acting on axonal receptors should increase or decrease the success rate. A variant of the method is to cycle the stimulus

A
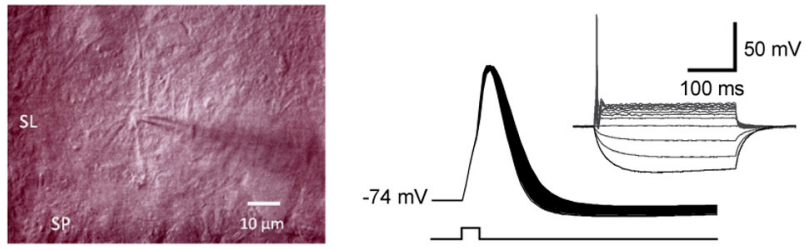

B

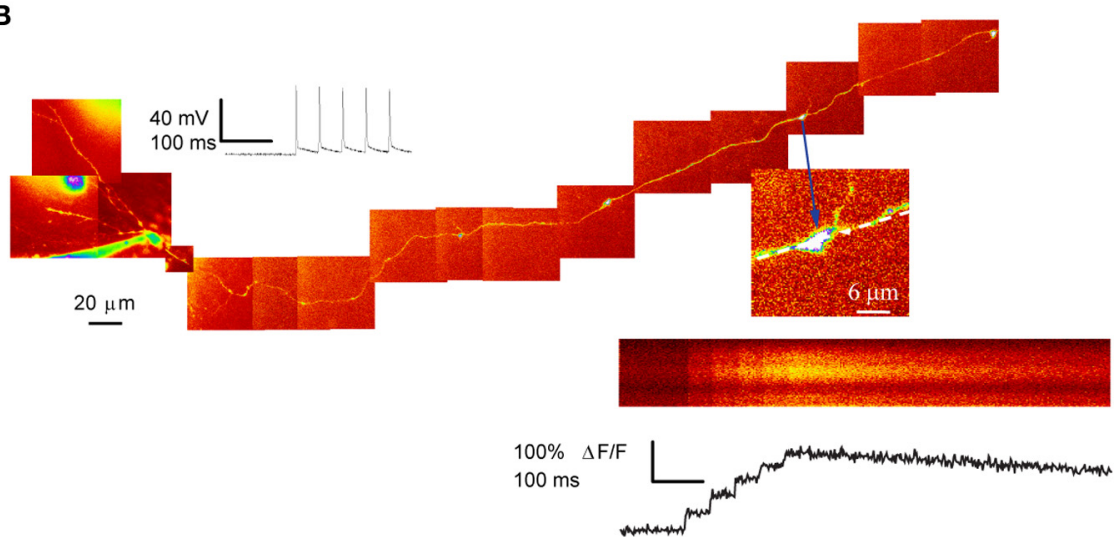

FIGURE 1 | Patch-clamp recording and 2-photon excitation fluorescence imaging from single giant mossy fiber boutons. (A) Left, IR-DIC photomicrograph of a putative mossy fiber bouton in juxtaposition with a dendrite located in stratum-lucidum. Right: action potentials evoked by a single depolarizing current step ( $1 \mathrm{nA}, 0.5 \mathrm{~ms})$ repeated at $50 \mathrm{~Hz}$. Note the spike broadening. Inset shows the $\mathrm{I}-\mathrm{V}$ relation ( -30 to $60 \mathrm{pA}, 300 \mathrm{~ms} ; 10 \mathrm{pA}$ increment). (B) $\mathrm{Ca}^{2+}$ imaging in a dentate granule cell filled with Alexa 594. The montage was obtained from Kalman-filtered averages of 10-15- $\mu \mathrm{m}$ stacks. Arrow indicates a giant mossy fiber bouton in stratum lucidum selected for imaging. Line-scan and fluorescence transients recorded from the same bouton, in response to five somatic action potentials. Panel $(\mathbf{A})$ image and AP traces courtesy of Dr. D. Engel and panel (B) from Scott and Rusakov (2006). 
through a saw-tooth intensity pattern ranging from 100\% failures to $100 \%$ success for evoking an action current. Here, the effect of the drug on axonal receptors is examined over the entire stimulus - response relation. However, a recurrent problem with these approaches is that they rely on the integrity of axonal projections connected to their parent somata, a situation that occurs in about $12-15 \%$ of our slices.

An important breakthrough that allowed direct assessment was the development of direct patch-clamp recordings from large mossy fiber terminals (Geiger and Jonas, 2000; Bischofberger et al., 2006), thus enabling a detailed characterization of the pharmacological and biophysical properties of presynaptic receptors at single channel level. Although these recordings have provided important insights into the relation between receptor activation and presynaptic membrane potential, they inevitably perturb intraterminal ionic gradients because the size of the bouton is very small in relation to the patch pipette. This is particularly problematic when measuring the membrane potential from whole-terminal recordings because this method clamps $\left[\mathrm{K}^{+}\right]_{\mathrm{i}}$ and because the input resistance of the clamped structure is comparable to the seal resistance (Verheugen et al., 1999; Tyzio et al., 2003). It also affects the $\left[\mathrm{Cl}^{-}\right]_{\mathrm{i}}$ which has been estimated $\sim 20 \mathrm{mM}$ in the Calyx of Held (Price and Trussell, 2006), therefore potentially compromising the driving force for $\mathrm{GABA}_{\mathrm{A}}$ receptor and glycine receptor mediated ion fluxes.

The membrane potential of mossy fiber boutons can in principle be estimated non-invasively (Fricker et al., 1999; Verheugen et al., 1999). When recording in bouton-attached mode with a high $\left[\mathrm{K}^{+}\right]$pipette solution and applying a voltage ramp (from a holding potential of -100 to $+200 \mathrm{mV}$ ), a $\mathrm{K}^{+}$conductance is activated such that the $\mathrm{K}^{+}$current reverses when the pipette potential is equal to the transmembrane potential. There are several shortcomings of this bouton-attached configuration mainly related to the small size of the patched structure: first, the $\left[\mathrm{K}^{+}\right]_{\mathrm{i}}$ in the terminal is unknown and is assumed to be as high as in the somatic compartment, but this potential source of error has only a minor influence (Fricker et al., 1999). Second, a major bias occurs when the seal resistance is equivalent or lower than the resistance of the patch, in which case, most of the $\mathrm{K}^{+}$current will be shunt (It should not however influence the potential at which the current changes polarity). That said, gramicidin perforated-patch recordings, which normally do not perturb $\left[\mathrm{Cl}^{-}\right]_{\mathrm{i}}$ have not been successfully applied to mossy fiber boutons.

Large mossy fiber varicosities can be visualized in living slices with two-photon excitation fluorescence imaging integrated with patch-clamp electrophysiology (Scott and Rusakov, 2006, 2008; Nistico et al., 2012). Granule cell loading with a morphological tracer such as Alexa Fluor $594(20-40 \mu \mathrm{M})$, together with a high-affinity $\mathrm{Ca}^{2+}$ indicator, Fluo-4 $(200 \mu \mathrm{M})$, or Oregon Green BAPTA-1 $(200 \mu \mathrm{M})$, then potentially allows $\mathrm{Ca}^{2+}$ signaling in unambiguously identified mossy fiber boutons. This depends on tracing the axon from the soma through the hilus and into stratum lucidum. The success rate for imaging a giant mossy fiber bouton in CA3 supplied by a given granule cell is however low, because it depends on the integrity of a lengthy mossy fiber connected to its parent soma.
Presynaptic ionotropic receptors can also been investigated in acutely dissociated CA3 pyramidal neurons, which can be isolated with adherent functional synaptic terminals. This technique (Akaike and Moorhouse, 2003) offers the advantage that single presynaptic terminals and boutons can be visualized using fluorescent markers and can be focally stimulated with a glass micropipette. Adherent contacts are functional and generate spontaneous postsynaptic currents over a reasonable period of time, thus enabling pharmacological manipulation of presynaptic receptors. The method has been successfully applied to CA3 pyramidal neurons (Jang et al., 2006). However, it is mainly restricted to proximal contacts since the dissociation procedure eliminates most of dendritic processes in postsynaptic neurons.

\section{PRESYNAPTIC GABA RECEPTORS $_{A}$}

Modulation of transmitter release at a synapse was first demonstrated in the pioneering studies of Dudel and Kuffler (1961) and Eccles (1964) who showed that presynaptic GABA receptors inhibited transmitter release from crustacean motor neuron terminals and vertebrate sensory neuron terminals in the spinal cord, respectively. Since then, presynaptic $\mathrm{GABA}_{\mathrm{A}}$ receptors have been described in the retina (Tachibana and Kaneko, 1984; Lukasiewicz and Werblin, 1994), the cerebellum (Trigo et al., 2007), the posterior pituitary (Zhang and Jackson, 1993), thalamic nuclei (Jang et al., 2001), and higher cortical structures where they have been shown to modulate axonal excitability and the release of neurotransmitters (Kullmann et al., 2005).

$\mathrm{GABA}_{\mathrm{A}}$ receptors depolarize presynaptic axons because $\left[\mathrm{Cl}^{-}\right]_{\mathrm{i}}$ is relatively high, reflecting absence of the main extrusion system KCC2 (Gulyas et al., 2001; Hubner et al., 2001). Opening of $\mathrm{GABA}_{\mathrm{A}}$ receptors may interfere with the propagation of action potentials by decreasing membrane resistivity (Segev, 1990; Cattaert and El Manira, 1999; Wachowiak and Cohen, 1999; Verdier et al., 2003; Alle and Geiger, 2007). Others have argued that $\mathrm{GABA}_{\mathrm{A}}$ receptor-mediated depolarization could decrease the driving force for $\mathrm{Ca}^{2+}$ and/or inactivate $\mathrm{Na}^{+}$channels (Graham and Redman, 1994). However, presynaptic depolarization consecutive to $\mathrm{GABA}_{\mathrm{A}}$ receptor activation enhances neurotransmitter release at the MNTB synapse in the auditory brainstem (Turecek and Trussell, 2001, 2002). This effect appears to be mediated by an increase in basal $\mathrm{Ca}^{2+}$ (Awatramani et al., 2005), and recent evidence suggests that $\mathrm{P} / \mathrm{Q}$-type $\mathrm{Ca}^{2+}$ channels can be enhanced in a $\left[\mathrm{Ca}^{2+}\right]_{\mathrm{i}}$-dependent manner (Ishikawa et al., 2005; Hori and Takahashi, 2009).

Nearly a decade ago, we provided the first demonstration that presynaptic $\mathrm{GABA}_{\mathrm{A}}$ receptors occur in axon terminals in the hippocampus (Ruiz et al., 2003). We obtained both ultrastructural and pharmacological evidence consistent with the presence of presynaptic GABA receptors containing $\alpha_{2}$ (Figure 2A) subunits (see also Jang et al., 2006; Alle and Geiger, 2007). By altering $\left[\mathrm{Cl}^{-}\right]_{\mathrm{i}}$ within individual granule cells we showed that the $\mathrm{GABA}_{\mathrm{A}}$ receptor agonist muscimol produced opposite changes in the probability for evoking antidromic action potentials (Figure 2B). Opposite effects on axonal excitability were also obtained by applying the $\mathrm{GABA}_{\mathrm{A}}$ receptor blocker SR95531 (gabazine) depending on $\left[\mathrm{Cl}^{-}\right]_{\mathrm{i}}$, suggesting that these receptors are tonically active. These results could only be explained by the 
presence of $\mathrm{GABA}_{\mathrm{A}}$ receptors on mossy fibers. Measurements of single channel openings of presynaptic $\mathrm{GABA}_{\mathrm{A}}$ receptors in outside-out patches from mossy fiber boutons yielded an estimate $36 \mathrm{pS}$ (Alle and Geiger, 2007), similar to the main conductance state of $\mathrm{GABA}_{\mathrm{A}}$ receptors found in other preparations (Jones and Westbrook, 1995; Turecek and Trussell, 2002), but slightly larger than our own measurements (24 pS; Ruiz et al., 2010). Their expression is also developmentally regulated. Nakamura et al. (2007) showed that mossy fiber $\mathrm{GABA}_{\mathrm{A}}$ receptors are involved in the activity-dependent facilitation of the fiber volley via depolarizing GABA actions, a phenomenon that gradually decreased with development and eventually vanished at around postnatal day 30. In contrast, Alle and Geiger (2007) found that functional presynaptic $\mathrm{GABA}_{\mathrm{A}}$ receptors are conserved during development as witnessed by the presence of $\mathrm{GABA}_{\mathrm{A}}$ receptor-mediated currents in mossy fiber boutons from 3 month old rats.

What is the normal mode of activation of these receptors? We demonstrated that mossy fiber excitability was modulated by trains of stimuli designed to release GABA from neighboring inhibitory synapses, implying that presynaptic $\mathrm{GABA}_{\mathrm{A}}$ receptors could be activated by GABA spillover (Ruiz et al., 2003). This finding was later confirmed by Alle and Geiger (2007) who characterized a slow and small amplitude current in mossy fiber boutons, in response to stimulus trains (Figure 2C). These spillover currents were abolished by application of the $\mathrm{GABA}_{\mathrm{A}}$ receptor antagonist gabazine, whereas blocking the main GABA
A

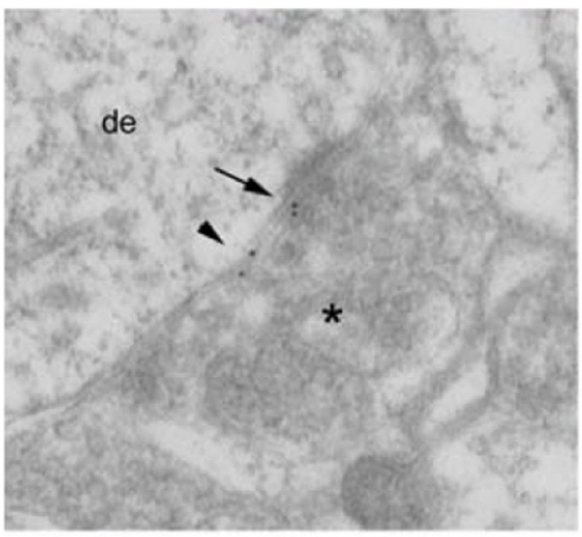

C

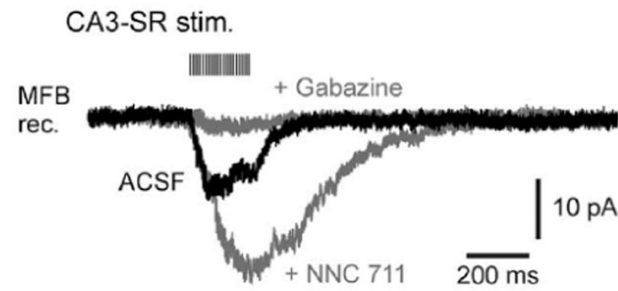

FIGURE 2 | Evidence for GABA $A_{A}$ receptors modulating mossy fiber excitability. (A) Post-embedding immunolocalization of the GABA $A_{A}$ receptor subunit $\alpha_{2}$ in a presumptive large mossy fiber terminal. (Asterisk indicates the presynaptic profile). Labeling is present at the synaptic cleft (arrow) and at extrasynaptic axonal membranes (small arrowhead). (B) Top, intermittent antidromic action currents. Local pressure application of the GABA $A_{A}$ agonist muscimol close to the stimulation site decreased the axon excitability. Bottom, following "break-in" with a pipette containing a high $\left[\mathrm{Cl}^{-}\right]$, the same application of muscimol caused an increase in axon excitability. Sweeps on the right are from one example cell. (C) Spill-over $\mathrm{GABA}_{\mathrm{A}}$ receptor-mediated
B
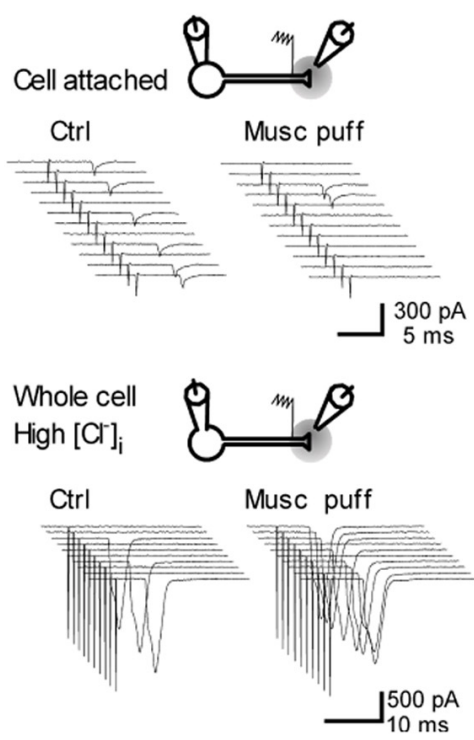

D

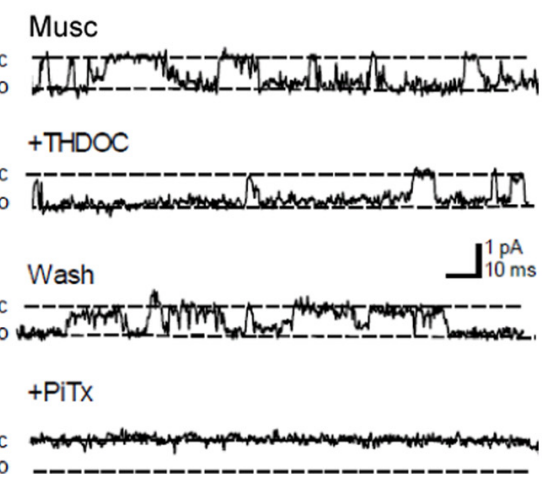

currents in a mossy fiber bouton held in voltage-clamp. Twenty pulses at $100 \mathrm{~Hz}$ applied to stratum radiatum in area CA3. Gray traces, successive bath application of the GAT 1 blocker NNC $711(1 \mu \mathrm{M})$ and the GABA receptor antagonist gabazine (10 $\mu \mathrm{M})$. (D) Muscimol-activated single channel currents in an outside-out patch from a mossy fiber bouton recorded with symmetrical $\left[\mathrm{Cl}^{-}\right]$. Superfusion of the neurosteroid THDOC (10 nM) reversibly prolongs the apparent open probability of the channel whereas the $\mathrm{GABA}_{A}$ receptor antagonist picrotoxine blocks the current. Panels (A, B, and $\mathbf{D})$ were reproduced from Ruiz et al. $(2003,2010)$ and panel (C) from Alle and Geiger (2007). 
uptake system GAT-1 with NNC-711 enhanced them. The results argued that presynaptic $\mathrm{GABA}_{\mathrm{A}}$ receptors can detect activitydependent fluctuations in the extracellular GABA concentration (see also Nakamura et al., 2007) as shown for a form of $\mathrm{GABA}_{\mathrm{B}}$ receptor-mediated signaling at these terminals (Vogt and Nicoll, 1999; Chandler et al., 2003; Safiulina and Cherubini, 2009).

Dentate granule cells express tonically active $\mathrm{GABA}_{\mathrm{A}}$ receptors, which are sensitive to physiological concentrations of tetrahydrodeoxycorticosterone (THDOC), an endogenous neurosteroid that is relatively selective for $\delta$-subunit containing receptors (Stell et al., 2003). We found that $10 \mathrm{nM}$ THDOC reversibly reduces the excitability of mossy fibers, mimicking the effect of $\mathrm{GABA}_{\mathrm{A}}$ receptor agonists and suggesting that high-affinity $\delta$-subunit containing receptors (in addition to $\alpha_{2}$ ) are present in the axon. Similar results were obtained with the hypnotic compound THIP (gaboxadol, $100 \mathrm{nM}$ ), which is a relatively selective agonist at $\mathrm{GABA}_{\mathrm{A}}$ receptors that lack $\gamma$ subunits. Finally, we confirmed that THDOC increased the apparent open probability of $\mathrm{GABA}_{\mathrm{A}}$ receptors in outside-out patches from mossy fiber boutons but had no effect on the single-channel conductance (Figure 2D).

We further showed that tonically-active presynaptic $\mathrm{GABA}_{\mathrm{A}}$ receptors depolarize mossy fibers and modulate the input resistance of mossy fiber boutons, as well as the shape of presynaptic action potentials (Figure 3A). Blocking $\mathrm{GABA}_{\mathrm{A}}$ receptors with gabazine hyperpolarized mossy fiber boutons and reduced spike half-width, whereas THDOC had the opposite depolarizing effect and broadened action potentials. These results diverged from those of Alle and Geiger (2007) who did not detect a change in mossy fiber bouton input resistance or membrane potential as a consequence of $\mathrm{GABA}_{\mathrm{A}}$ receptor blockade. The reason for this discrepancy is unclear but it could involve differences in rat strains (Wistar vs. Sprague-Dawley), recording temperature and state of neuromodulation, for example by zinc or dynorphin. Notwithstanding these differences, the presence of both high- and low-affinity presynaptic $\mathrm{GABA}_{\mathrm{A}}$ receptors suggests a richness of phasic and tonic modulation of synaptic transmission at mossy fiber-CA3 synapses.

We also detected a strong influence of $\mathrm{GABA}_{\mathrm{A}}$ receptors on action-potential dependent $\mathrm{Ca}^{2+}$ transients in single axonal varicosities imaged with 2-photon excitation fluorescence microscopy (Figure 3B). We showed that the $\mathrm{GABA}_{\mathrm{A}}$ receptor antagonist gabazine decreased the amplitude of action-potential evoked $\mathrm{Ca}^{2+}$ transients whereas THDOC had the opposite effect. These results demonstrated that tonically-active $\mathrm{GABA}_{\mathrm{A}}$ receptors contribute to presynaptic depolarization and $\mathrm{Ca}^{2+}$ influx when a single action potential invades a mossy fiber varicosity. To assess the

A

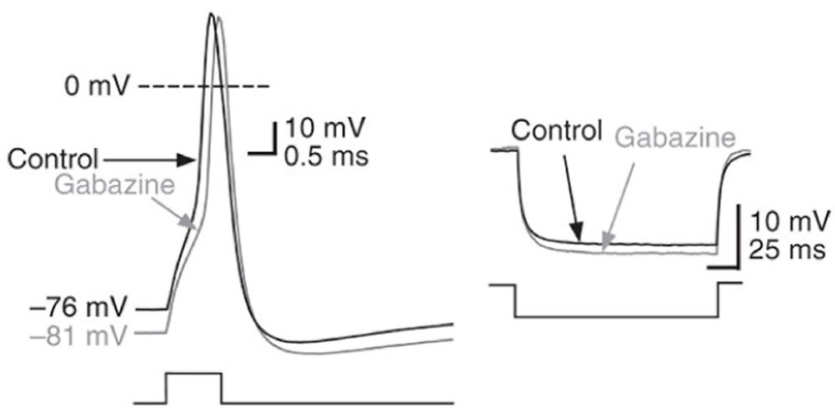

B
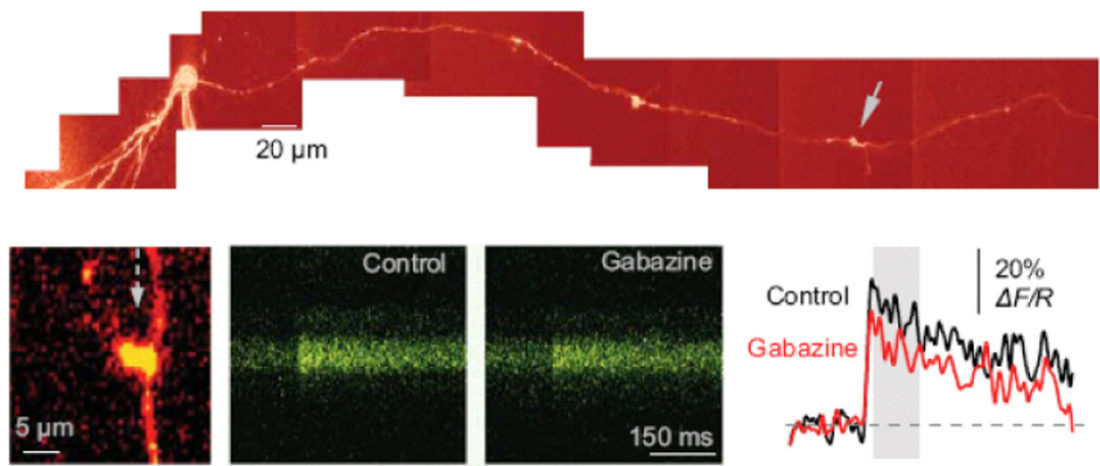

FIGURE 3 | Tonically-active GABA receptor-mediated currents modulate the electrical properties of mossy fiber boutons. (A) Current-clamp recording from a mossy fiber bouton with $\left.20 \mathrm{mM} \mathrm{Cl}^{-}\right]_{j}$. Left, sample traces showing the action potential before (black) and after (gray) superfusion of gabazine $(5 \mu \mathrm{M})$. Right, response to hyperpolarizing current injection showing an increase in mossy fiber input resistance in gabazine. (B) Tonically-active $\mathrm{GABA}_{\mathrm{A}}$ receptors enhance presynaptic action potential-dependent $\mathrm{Ca}^{2+}$ transients in giant mossy fiber boutons. Top, reconstruction of a dentate granule cell (Alexa Fluor 594 channel, $\lambda x=800 \mathrm{~nm}$ ). Arrows indicate giant boutons with characteristic thin filopodia. Bottom, blocking $G_{A B A}$ receptors with gabazine reduced spike-dependent presynaptic $\mathrm{Ca}^{2+}$ entry. Line scans and traces are $\mathrm{Ca}^{2+}$ responses in the mossy fiber bouton shown on the left following a single action potential induced at the soma, in control conditions and in $1 \mu \mathrm{M}$ gabazine. Reproduced from Ruiz et al. (2010). 
contribution of presynaptic $\mathrm{GABA}_{\mathrm{A}}$ receptors to glutamatergic transmission we recorded from CA3 pyramidal neurons with a pipette solution containing $\mathrm{CsF}$ and $4,4^{\prime}$-diisothiocyanostilbene2,2'-disulfonic acid (DIDS) to block postsynaptic $\mathrm{GABA}_{\mathrm{A}}$ receptors intracellularly, while leaving presynaptic receptors unaffected (Figure 4A). Local pressure application of THDOC reversibly increased the amplitude of evoked excitatory postsynaptic currents (EPSCs) whereas gabazine decreased it, implying that presynaptic $\mathrm{GABA}_{\mathrm{A}}$ receptor normally exert a bidirectional control over dentate gyrus - CA3 neurotransmission. Finally, we demonstrated that blocking presynaptic $\mathrm{GABA}_{\mathrm{A}}$ receptors impaired the induction of mossy fiber LTP (Figure 4B). A straightforward explanation for this finding was that tonic $\mathrm{GABA}_{\mathrm{A}}$ receptor mediated presynaptic depolarization has a permissive role in mossy fiber LTP because its induction is steeply dependent on the presynaptic membrane potential and $\mathrm{Ca}^{2+}$ influx
(Castillo et al., 1994; Schmitz et al., 2003; Nicoll and Schmitz, 2005). Although the evidence for presynaptic $\mathrm{GABA}_{\mathrm{A}}$ receptors is compelling some puzzles remain. For instance, muscimol decreases mossy fiber excitability even though $\mathrm{GABA}_{\mathrm{A}}$ receptor activation depolarizes boutons (Alle and Geiger, 2007; Ruiz et al., 2010). Reduced excitability can potentially be explained by partial inactivation of $\mathrm{Na}^{+}$channels. Furthermore, although differences in apparent affinity of $\mathrm{GABA}_{\mathrm{A}}$ receptors suggest that multiple biophysically distinct receptors coexist in the same boutons they have not been resolved at single channel resolution.

\section{PRESYNAPTIC GLYCINE RECEPTORS}

Glycine is a common neurotransmitter in the spinal cord and the brainstem whose action on glycine receptors activates a $\mathrm{Cl}^{-}$ conductance. Glycine and glycine receptors are, however, not

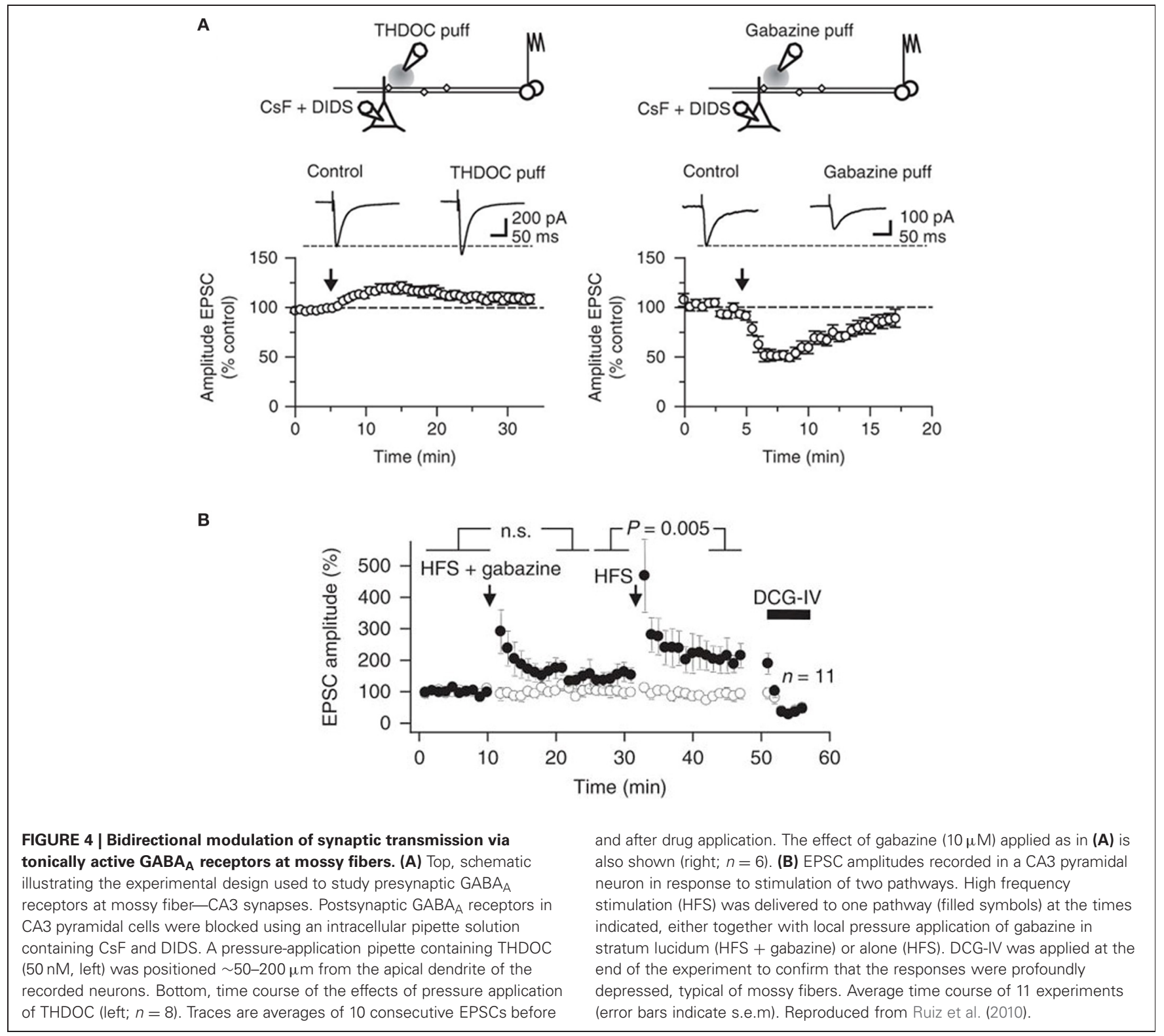


A

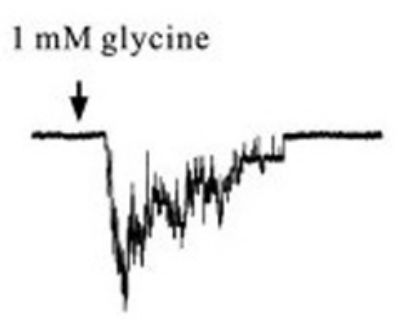

B

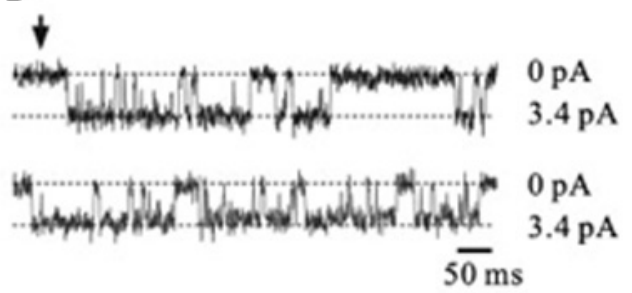

C
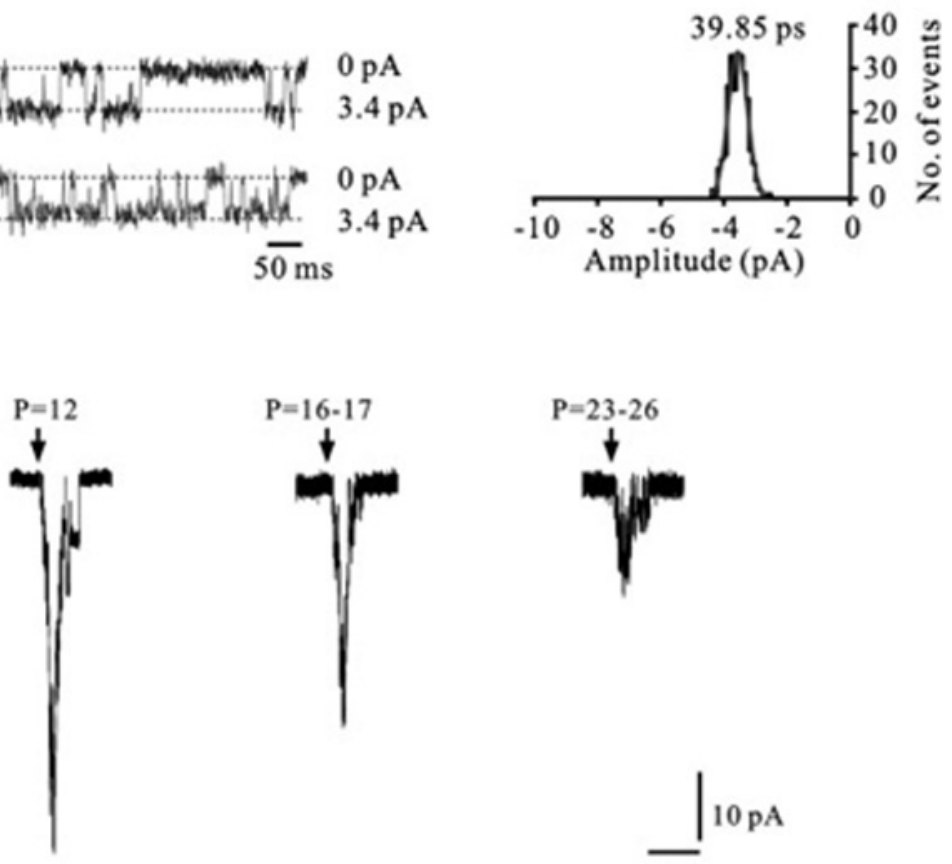

$2 \mathrm{~s}$

$+3 \mu \mathrm{M}$ Strychnine

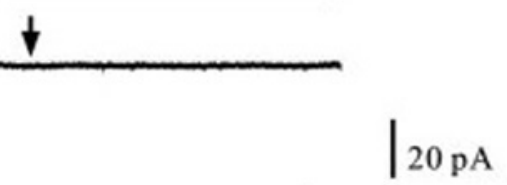


restricted to these regions, nor do they always promote inhibition. Glycine receptors have been reported in the cerebellum and the hippocampus (Araki et al., 1988). Glycine receptors in the forebrain are mainly found at extrasynaptic sites in postsynaptic membranes or even presynaptically (Harvey and Rigo, 2010). In the retina, presynaptic glycine receptors localize in rod cells terminals where they inhibit transmission by hyperpolarization and a shunting mechanism (Morkve and Hartveit, 2009). Presynaptic glycine receptors enhance glutamate release at the MNTB synapse by promoting small depolarization's of the nerve terminal (Turecek and Trussell, 2001). Interestingly, presynaptic glycine receptor activation in the ventral tegmental area enhances GABA release in young neurons but has an inhibitory effect in older neurons (Ye et al., 2004). Thus, the direction in which transmitter release is regulated by presynaptic glycine receptors varies within the CNS and during development, and this can affect both excitatory and inhibitory neurotransmitters.

In the hippocampus, the evidence for functional presynaptic glycine receptors is sparse. Exogenously applied glycine significantly increased the frequency of spontaneous EPSCs recorded from mechanically dissociated rat dentate hilar neurons attached with native presynaptic nerve terminals (Lee et al., 2009). The enhancing effect of glycine on synaptic transmission was blocked by the specific glycine receptor antagonist strychnine, but was unaffected by picrotoxin. The evidence that these receptors are expressed at mossy fibers again comes from direct patch-clamp recordings and single channel analysis (Kubota et al., 2010). As shown in Figure 5A, immature mossy fiber boutons challenged with glycine displayed inward currents that were blocked by strychnine. Glycine-gated channels showed a main conductance of $40 \mathrm{pS}$ (Figure 5B) but multiple conductance states were observed, consistent with expression of both homo- and heterooligomeric glycine receptors (Takahashi and Momiyama, 1991; Singer and Berger, 1999). The expression profile of presynaptic glycine receptors at mossy fibers declined dramatically with age (Figure 5C) in sharp contrast with those found at the Calyx of Held (Turecek and Trussell, 2001, 2002).

\section{PRESYNAPTIC NMDA RECEPTORS}

One of the first demonstration that presynaptic NMDA receptors occur on axon terminals in the CNS came from the immunolocalization of the NMDA receptor subunit NR1 in both the dorsal and ventral horns of the rat spinal cord, particularly near the active zones, suggesting a modulatory role in transmitter release (Liu et al., 1994). These receptors were later found to modulate the release of glutamate and substance P from nociceptive fibers (Liu et al., 1997) and glutamate release from primary sensory neurons (Bardoni et al., 2004). In the cerebellum, presynaptic NMDA receptors facilitate GABA release at basket cell-Purkinje cell synapses via retrograde signaling and release of $\mathrm{Ca}^{2+}$ from internal stores (Duguid and Smart, 2004). In cortical regions, Berretta and Jones (1996) introduced a trick to specifically block NMDA receptors in postsynaptic cells, leaving presynaptic NMDA receptors available for pharmacological manipulation. They recorded in whole-cell mode from layer II enthorinal cortex neurons with a pipette solution containing $1 \mathrm{mM}$ MK-801 to block NMDA receptors intracellularly. They showed that superfusion of the
NMDA receptor antagonist D-AP5 resulted in a decrease of the frequency of miniature EPSCs with little effect on the amplitude, suggesting that tonically-activated NMDA receptors facilitate glutamate release also at cortical synapses. Finally, in the juvenile rat barrel cortex, presynaptic NR2B-containing NMDA receptors enhance AMPA receptor-mediated synaptic transmission at layer 4 to layers 2/3 synapses (Brasier and Feldman, 2008).

Recently, presynaptic NMDA receptors have been implicated in spike-timing dependent long-term depression at neocortical synapses (Sjostrom et al., 2003; Buchanan et al., 2012). This process requires the co-activation of $\mathrm{CB} 1$ receptors and is developmentally regulated such that in the juvenile, the NR3A subunit enhances spontaneous and evoked glutamate release and is required for spike timing-dependent long-term depression, whereas in the adult, NR2B-containing presynaptic NMDA receptors enhance neurotransmission in the absence of $\mathrm{Mg}^{2+}$, implying that they function under depolarizing conditions. Recently, a new caged compound has demonstrated axonal NMDA receptors required for induction and the presynaptic locus of expression of LTD at layer 4-layer 2/3 synapses (Rodriguez-Moreno et al., 2012). The evidence for presynaptic NMDA receptors in cortical neurons is however incomplete, and one study failed to detect them using axonal $\mathrm{Ca}^{2+}$ imaging (Pugh and Jahr, 2012).

Evidence for presynaptic NMDA receptors at mossy fiber synapses is also incomplete. In the monkey hippocampus, monoclonal antibodies raised against the NMDA receptor subunits NR1 and NR2 stained stratum lucidum but not postsynaptic targets (Siegel et al., 1994). The detection of NMDA receptors subunits in the mossy fiber projection zone does not, however, prove the presence of functionally active presynaptic receptors. A study reporting NMDA receptors using patch-clamp recordings from mossy fiber boutons has only been reported in abstract form (Alle and Geiger, 2005). Thus, evidence that NMDA receptors are expressed in mossy fiber terminals is far from conclusive.

\section{PRESYNAPTIC KAINATE RECEPTORS}

In contrast with AMPA and NMDA receptors, kainate receptors play a relatively small role in fast glutamatergic transmission at most synapses. Some exceptions are mossy fiber synapses, and thalamo-cortical synapses early in development, where they mediate slow and small amplitude EPSCs (Castillo et al., 1997; Vignes and Collingridge, 1997; Kidd et al., 2002). There is however, abundant evidence for kainate receptor expression in presynaptic terminals where they modulate the plastic properties of both excitatory and inhibitory connections (reviewed by Kullmann, 2001; Pinheiro and Mulle, 2008; Contractor et al., 2012). In the hippocampus, early binding studies using (3) $\mathrm{H}$ radiolabelled kainate as ligand (Foster et al., 1981; Monaghan and Cotman, 1982; Bahn et al., 1994) have shown the presence of high-affinity binding sites restricted to stratum lucidum, where mossy fibers terminate. This staining pattern was dramatically reduced by selective destruction of dentate granule cells with the antimitotic agent colchicine (Represa et al., 1987), suggesting that kainate receptors are expressed in the axon or in presynaptic terminals. Immunohistochemical experiments with monoclonal antibodies directed against GluK1 and GluK2 also stained stratum lucidum (Petralia et al., 1994), in line with previous results. 
The effects of kainate on dentate gyrus - CA3 neurotransmission are concentration-dependent and bimodal: superfusion of a low dose of kainate (50-200 nM) has been reported to facilitate evoked EPSC recorded in CA3 pyramidal neurons whereas higher doses $(1-5 \mu \mathrm{M})$ have a depressant effect. The facilitation of mossy fiber EPSCs consecutive to the application of a low concentration of kainate is accompanied by an enhancement of the presynaptic fiber volley (Figure 6A; Kamiya and Ozawa, 2000; Schmitz et al., 2001) and by a decrease in the threshold for evoking antidromic action potentials recorded in granule cells (Kamiya and Ozawa, 2000), consistent with a presynaptic expression of kainate receptors. One explanation for these effects is that mild depolarization could inactivate $\mathrm{K}^{+}$channels whereas inactivation of presynaptic $\mathrm{Ca}^{2+}$ channels may occur with large doses of kainate. Presynaptic kainate eceptors could be activated by synaptic release of glutamate from neighboring mossy fibers or associational-commisural fibers, thus mimicking the effect of exogenous agonist application on the fiber volley and threshold (Schmitz et al., 2000).

Although kainate receptors contribute to the large frequencydependent short-term plasticity of mossy fiber synapses, the identity of the subunits that mediate these effects is unclear.
Studies performed in knock-out mice indicate that presynaptic kainate receptors containing the GluK2 (Contractor et al., 2001; Breustedt and Schmitz, 2004; Rodriguez-Moreno and Sihra, 2007) and GluK3 subunits (Pinheiro et al., 2007; Perrais et al., 2009) facilitate the induction of this form of synaptic plasticity whereas other studies have identified GluK1 as a principal player (Bortolotto et al., 1999; Lauri et al., 2001; More et al., 2004). The reasons for these discrepancies are unknown, but some of the GluK1 antagonists used in these studies could also block receptors containing the GluK3 subunit (Perrais et al., 2009). GluK3 is thought to underlie the effects mediated by presynaptic kainate receptors. Receptors containing this subunit have a low sensitivity for glutamate, are highly $\mathrm{Ca}^{2+}$-permeable, desensitize rapidly and are subject to a voltage-dependent block by intracellular spermine. However, the view that kainate receptors participate in short-term plasticity at mossy fiber-CA3 synapses was recently challenged by Kwon and Castillo (2008). The authors found no evidence that presynaptic kainate receptors facilitate transmitter release on CA3 pyramidal neurons over a wide range of stimulus frequencies delivered to mossy fibers, and argued that actions generally attributed to presynaptic

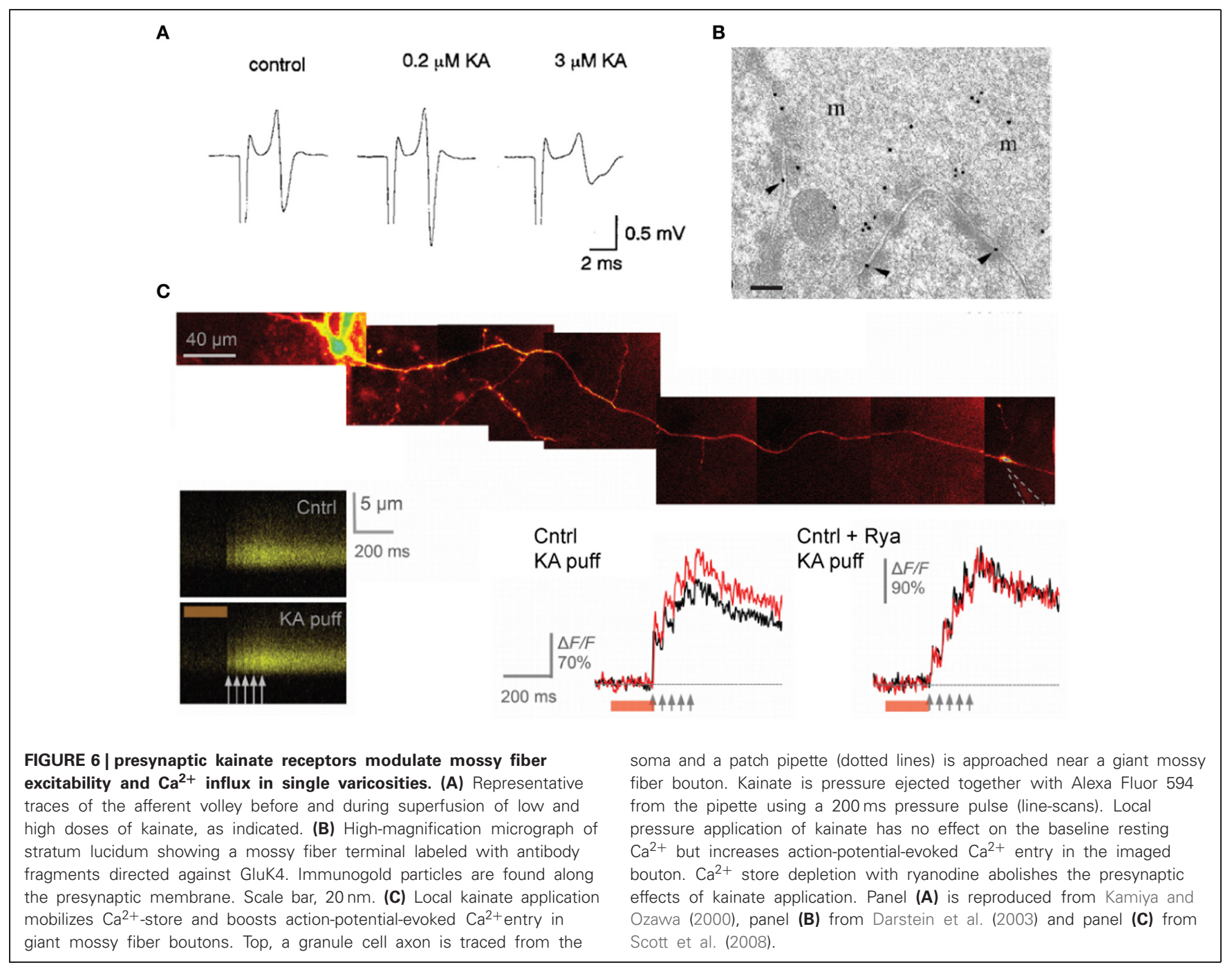


kainate receptors are likely due to activation of the recurrent CA3 network.

Two studies have provided solid and direct evidence that these receptors actually occur in presynaptic and perisynaptic membranes in mossy fibers. The first study is the immunolocalization of kainate receptor subunits at ultrastructural level performed by Darstein et al. (2003). The authors showed that both GluK4 and GluK5 subunits localize presynaptically, with a preferential expression for GluK4, whereas GluK5 is mainly found in postsynaptic membranes (Figure 6B). Interestingly, antibodies against these two subunits also pulled-down GluK2 in hippocampal membrane extracts but failed to detect GluK3 subunits, whose localization is thought to be presynaptic (Pinheiro et al., 2007). The second report by Scott et al. (2008) used high resolution multi-photon imaging and pharmacology. Here the authors showed that individual action potentials evoke an increase in intracellular $\mathrm{Ca}^{2+}$ in presynaptic varicosities which is enhanced by kainate receptor activation, and contribute to activity-dependent facilitation of synaptic transmission in CA3 pyramidal neurons (Figure 6C). Whether glutamate released from a single varicosity acts on kainate receptors located on that same varicosity remains, however, to be demonstrated.

Kainate receptors are also thought to facilitate the induction of long-term potentiation in CA3 pyramidal neurons (Bortolotto et al., 1999; Lauri et al., 2001; Schmitz et al., 2003; Pinheiro et al., 2007). Again, conflictive reports have emerged in the literature about their role in the phenomenon (Kullmann, 2001). Recently, it has been argued that differences in kainate receptor involvement in mossy fiber long-term potentiation depend on slice orientation (Sherwood et al., 2012). In transverse slices, LTP was found resistant to GluK1 antagonists whereas in parasagittal slices LTP was consistently blocked by these agents. Whatever the explanations, we believe that many answers will come from direct recordings from mossy fiber boutons and a detailed characterization of the effects of kainate on the presynaptic membrane potential.

\section{REFERENCES}

Acsady, L., Kamondi, A., Sik, A., Freund, T., and Buzsaki, G. (1998). GABAergic cells are the major postsynaptic targets of mossy fibers in the rat hippocampus. J. Neurosci. 18, 3386-3403.

Akaike, N., and Moorhouse, A. J. (2003). Techniques: applications of the nerve-bouton preparation in neuropharmacology. Trends Pharmacol. Sci. 24, 44-47.

Alle, H., and Geiger, J. R. (2005). NMDA receptors in hippocampal mossy fibers. Acta Physiol. 186(Suppl.), 650.

Alle, H., and Geiger, J. R. (2007). GABAergic spill-over transmission onto hippocampal mossy fiber boutons. J. Neurosci. 27, 942-950.

Amaral, D. G., Ishizuka, N., and Claiborne, B. (1990). Neurons,

\section{FUNCTIONAL IMPLICATIONS}

Presynaptic modulation via ionotropic receptors may have broader implications for information processing and hippocampal physiology than previously thought. Endogenous levels of glutamate, GABA or glycine in brain tissue seem sufficient to promote baseline activity of high-affinity receptors, whereas receptors with lower affinities might be activated only after sustained activity and during a short time window consecutive to neurotransmitter release. For example, presynaptic kainate receptors at thalamo-cortical synapses depress glutamate release during repetitive activation at frequencies $>50 \mathrm{~Hz}$ (Kidd et al., 2002), but presynaptic $\mathrm{GABA}_{A}$ receptors at mossy fibers regulate glutamate release when presynaptic activity spans a wider range of frequencies (Nakamura et al., 2007). Presynaptic ionotropic receptors are also subject to neuromodulation from a large variety of hormones, cations, and other neurotransmitters, including monoamines and neurosteroids, whose levels fluctuate extensively in physiological states and behavioral tasks as well as in pathological conditions. Finally, the permissive and synergistic effect of presynaptic $\mathrm{GABA}_{A}$ and kainate receptors on mossy fiber LTP highlight a powerful mechanism for information storage in CA3 networks. It also serves the basis for homeostatic regulation of feed-forward and frequency-tuned inhibition at a major input to the hippocampus proper.

\section{CONCLUSIONS}

An increasing diversity of receptors normally found in dendrites are also localized in axon terminals where they mediate fast and local regulation of presynaptic excitability, $\mathrm{Ca}^{2+}$ influx and neurotransmitter release. A common feature of these receptors is that their activation leads to membrane depolarization and shunting, which in turn alter spike shape and the relation between $\mathrm{Ca}^{2+}$ influx and release probability. Direct recordings from mossy fiber boutons have provided some of the most compelling insights into the identity, localization, and physiological roles of these receptors.

release from primary sensory neurons in rat spinal cord dorsal horn. J. Neurosci. 24, 2774-2781.

Berretta, N., and Jones, R. S. (1996). Tonic facilitation of glutamate release by presynaptic N-methyl$\mathrm{D}$-aspartate autoreceptors in the entorhinal cortex. Neuroscience 75, 339-344.

Bischofberger, J., Engel, D., Li, L., Geiger, J. R., and Jonas, P. (2006). Patch-clamp recording from mossy fiber terminals in hippocampal slices. Nat. Protoc. 1, 2075-2081.

Bortolotto, Z. A., Clarke, V. R., Delany, C. M., Parry, M. C., Smolders, I., Vignes, M., et al. (1999). Kainate receptors are involved in synaptic plasticity. Nature 402, 297-301.

Brasier, D. J., and Feldman, D. E. (2008). Synapse-specific expression of functional presynaptic NMDA receptors in rat somatosensory cortex. J. Neurosci. 28, 2199-2211.

Breustedt, J., and Schmitz, D. (2004). Assessing the role of GLUK5 and GLUK6 at hippocampal mossy fiber synapses. J. Neurosci. 24, 10093-10098.

Buchanan, K. A., Blackman, A. V., Moreau, A. W., Elgar, D., Costa, R. P., Lalanne, T., et al. (2012). Target-specific expression of presynaptic NMDA receptors in neocortical microcircuits. Neuron 75, 451-466.

Castillo, P. E., Malenka, R. C., and Nicoll, R. A. (1997). Kainate receptors mediate a slow postsynaptic current in hippocampal CA3 neurons. Nature 388, 182-186.

Castillo, P. E., Weisskopf, M. G., and Nicoll, R. A. (1994). The role of $\mathrm{Ca} 2+$ channels in hippocampal mossy fiber synaptic transmission 
and long-term potentiation. Neuron $12,261-269$.

Cattaert, D., and El Manira, A. (1999). Shunting versus inactivation: analysis of presynaptic inhibitory mechanisms in primary afferents of the crayfish. J. Neurosci. 19, 6079-6089.

Chandler, K. E., Princivalle, A. P., Fabian-Fine, R., Bowery, N. G., Kullmann, D. M., and Walker, M. C. (2003). Plasticity of GABA(B) receptor-mediated heterosynaptic interactions at mossy fibers after status epilepticus. J. Neurosci. 23, 11382-11391.

Contractor, A., Mulle, C., and Swanson, G. T. (2012). Kainate receptors coming of age: milestones of two decades of research. Trends Neurosci. 34, 154-163.

Contractor, A., Swanson, G., and Heinemann, S. F. (2001). Kainate receptors are involved in shortand long-term plasticity at mossy fiber synapses in the hippocampus. Neuron 29, 209-216.

Darstein, M., Petralia, R. S., Swanson, G. T., Wenthold, R. J., and Heinemann, S. F. (2003). Distribution of kainate receptor subunits at hippocampal mossy fiber synapses. J. Neurosci. 23, 8013-8019.

Dudel, J., and Kuffler, S. W. (1961). Presynaptic inhibition at the crayfish neuromuscular junction. J. Physiol. 155, 543-562.

Duguid, I. C., and Smart, T. G. (2004). Retrograde activation of presynaptic NMDA receptors enhances GABA release at cerebellar interneuron-Purkinje cell synapses. Nat. Neurosci. 7, 525-533.

Eccles, J. C. (1964). Presynaptic inhibition in the spinal cord. Prog. Brain Res. 12, 65-91.

Edwards, F. R., Harrison, P. J., Jack, J. J., and Kullmann, D. M. (1989). Reduction by baclofen of monosynaptic EPSPs in lumbosacral motoneurones of the anaesthetized cat. J. Physiol. (Lond.) 416, 539-556.

Foster, A. C., Mena, E. E., Monaghan, D. T., and Cotman, C. W. (1981). Synaptic localization of kainic acid binding sites. Nature 289, 73-75.

Fricker, D., Verheugen, J. A., and Miles, R. (1999). Cell-attached measurements of the firing threshold of rat hippocampal neurones. J. Physiol. 517(Pt 3), 791-804.

Geiger, J. R., and Jonas, P. (2000). Dynamic control of presynaptic $\mathrm{Ca}(2+)$ inflow by fast-inactivating $\mathrm{K}(+)$ channels in hippocampal mossy fiber boutons. Neuron 28, 927-939.
Graham, B., and Redman, S. (1994). A simulation of action potentials in synaptic boutons during presynaptic inhibition. J. Neurophysiol. 71, 538-549.

Gulyas, A. I., Sik, A., Payne, J. A., Kaila, K., and Freund, T. F. (2001). The $\mathrm{KCl}$ cotransporter, $\mathrm{KCC} 2$, is highly expressed in the vicinity of excitatory synapses in the rat hippocampus. Eur. J. Neurosci. 13, 2205-2217.

Harvey, R. J., and Rigo, J. M. (2010). Glycinergic transmission: physiological, developmental and pathological implications. Front. Mol. Neurosci. 3:115. doi: 10.3389/fnmol.2010.00115

Henze, D. A., Wittner, L., and Buzsaki, G. (2002). Single granule cells reliably discharge targets in the hippocampal CA3 network in vivo. Nat. Neurosci. 5, 790-795.

Hori, T., and Takahashi, T. (2009). Mechanisms underlying short-term modulation of transmitter release by presynaptic depolarization. J. Physiol. 587, 2987-3000.

Hubner, C. A., Stein, V., HermansBorgmeyer, I., Meyer, T., Ballanyi, K., and Jentsch, T. J. (2001). Disruption of KCC2 reveals an essential role of $\mathrm{K}-\mathrm{Cl}$ cotransport already in early synaptic inhibition. Neuron 30, 515-524.

Ishikawa, T., Kaneko, M., Shin, H. S., and Takahashi, T. (2005). Presynaptic N-type and P/Q-type $\mathrm{Ca} 2+$ channels mediating synaptic transmission at the calyx of Held of mice. J. Physiol. 568, 199-209.

Jang, I. S., Jeong, H. J., and Akaike, N. (2001). Contribution of the $\mathrm{Na}$ $\mathrm{K}-\mathrm{Cl}$ cotransporter on GABA(A) receptor-mediated presynaptic depolarization in excitatory nerve terminals. J. Neurosci. 21, 5962-5972.

Jang, I. S., Nakamura, M., Ito, Y., and Akaike, N. (2006). Presynaptic GABAA receptors facilitate spontaneous glutamate release from presynaptic terminals on mechanically dissociated rat CA3 pyramidal neurons. Neuroscience 138, 25-35.

Jones, M. V., and Westbrook, G. L. (1995). Desensitized states prolong GABAA channel responses to brief agonist pulses. Neuron 15, 181-191.

Jung, M. W., and McNaughton, B. L. (1993). Spatial selectivity of unit activity in the hippocampal granular layer. Hippocampus 3, 165-182.

Kamiya, H., and Ozawa, S. (2000). Kainate receptor-mediated presynaptic inhibition at the mouse hippocampal mossy fibre synapse. J. Physiol. 523(Pt 3), 653-665.

Kidd, F. L., Coumis, U., Collingridge, G. L., Crabtree, J. W., and Isaac,
J. T. (2002). A presynaptic kainate receptor is involved in regulating the dynamic properties of thalamocortical synapses during development. Neuron 34, 635-646.

Kirischuk, S., Clements, J. D., and Grantyn, R. (2002). Presynaptic and postsynaptic mechanisms underlie paired pulse depression at single GABAergic boutons in rat collicular cultures. J. Physiol. 543, 99-116.

Kubota, H., Alle, H., Betz, H., and Geiger, J. R. (2010). Presynaptic glycine receptors on hippocampal mossy fibers. Biochem. Biophys. Res. Commun. 393, 587-591.

Kullmann, D. M. (2001). Presynaptic kainate receptors in the hippocampus: slowly emerging from obscurity. Neuron 32, 561-564.

Kullmann, D. M., Ruiz, A., Rusakov, D. M., Scott, R., Semyanov, A., and Walker, M. C. (2005). Presynaptic, extrasynaptic and axonal GABAA receptors in the CNS: where and why? Prog. Biophys. Mol. Biol. 87, 33-46.

Kwon, H. B., and Castillo, P. E. (2008). Role of glutamate autoreceptors at hippocampal mossy fiber synapses. Neuron 60, 1082-1094.

Lauri, S. E., Bortolotto, Z. A., Bleakman, D., Ornstein, P. L., Lodge, D., Isaac, J. T., et al. (2001). A critical role of a facilitatory presynaptic kainate receptor in mossy fiber LTP. Neuron 32, 697-709.

Lee, E. A., Cho, J. H., Choi, I. S. Nakamura, M., Park, H. M., Lee, J. J., et al. (2009). Presynaptic glycine receptors facilitate spontaneous glutamate release onto hilar neurons in the rat hippocampus. J. Neurochem. 109, 275-286.

Liu, H., Mantyh, P. W., and Basbaum, A. I. (1997). NMDA-receptor regulation of substance $\mathrm{P}$ release from primary afferent nociceptors. Nature 386, 721-724.

Liu, H., Wang, H., Sheng, M., Jan, L. Y., Jan, Y. N., and Basbaum, A. I. (1994). Evidence for presynaptic N-methyl-D-aspartate autoreceptors in the spinal cord dorsal horn. Proc. Natl. Acad. Sci. U.S.A. 91, 8383-8387.

Lukasiewicz, P. D., and Werblin, F. S. (1994). A novel GABA receptor modulates synaptic transmission from bipolar to ganglion and amacrine cells in the tiger salamander retina. J. Neurosci. 14, 1213-1223.

Manabe, T., Wyllie, D. J., Perkel, D. J., and Nicoll, R. A. (1993). Modulation of synaptic transmission and long-term potentiation: effects on paired pulse facilitation and EPSC variance in the CA1 region of the hippocampus. J. Neurophysiol. 70, 1451-1459.

Monaghan, D. T., and Cotman, C. W. (1982). The distribution of $[3 \mathrm{H}]$ kainic acid binding sites in rat CNS as determined by autoradiography. Brain Res. 252, 91-100.

More, J. C., Nistico, R., Dolman, N. P., Clarke, V. R., Alt, A. J., Ogden, A. M., et al. (2004). Characterisation of UBP296: a novel, potent and selective kainate receptor antagonist. Neuropharmacology 47, 46-64.

Morkve, S. H., and Hartveit, E. (2009). Properties of glycine receptors underlying synaptic currents in presynaptic axon terminals of rod bipolar cells in the rat retina. J. Physiol. 587, 3813-3830.

Nakamura, M., Sekino, Y., and Manabe, T. (2007). GABAergic interneurons facilitate mossy fiber excitability in the developing hippocampus. J. Neurosci. 27, 1365-1373.

Nicoll, R. A., and Schmitz, D. (2005). Synaptic plasticity at hippocampal mossy fibre synapses. Nat. Rev. Neurosci. 6, 863-876.

Nistico, R., Dargan, S. L., Amici, M., Collingridge, G. L., and Bortolotto, Z. A. (2012). Synergistic interactions between kainate and mGlu receptors regulate bouton $\mathrm{Ca}$ signalling and mossy fibre LTP. Sci. Rep. 1, 103.

Perrais, D., Coussen, F., and Mulle, C. (2009). Atypical functional properties of GluK3-containing kainate receptors. J. Neurosci. 29, 15499-15510.

Perrais, D., Pinheiro, P. S., Jane, D. E., and Mulle, C. (2009). Antagonism of recombinant and native GluK3 containing kainate receptors. Neuropharmacology 56, 131-140.

Perrais, D., and Ropert, N. (1999). Effect of zolpidem on miniature IPSCs and occupancy of postsynaptic GABAA receptors in central synapses. J. Neurosci. 19, 578-588.

Petralia, R. S., Wang, Y. X., and Wenthold, R. J. (1994). Histological and ultrastructural localization of the kainate receptor subunits, KA2 and GluR6/7, in the rat nervous system using selective antipeptide antibodies. J. Comp. Neurol. 349, 85-110.

Pinheiro, P. S., and Mulle, C. (2008). Presynaptic glutamate receptors: physiological functions and mechanisms of action. Nat. Rev. Neurosci. 9, 423-436.

Pinheiro, P. S., Perrais, D., Coussen, F., Barhanin, J., Bettler, B., Mann, J. R., et al. (2007). GluR7 is an essential subunit of presynaptic 
kainate autoreceptors at hippocampal mossy fiber synapses. Proc. Natl. Acad. Sci. U.S.A. 104, 12181-12186.

Price, G. D., and Trussell, L. O. (2006). Estimate of the chloride concentration in a central glutamatergic terminal: a gramicidin perforated-patch study on the calyx of Held. J. Neurosci. 26, 11432-11436.

Pugh, J. R., and Jahr, C. E. (2012). NMDA receptor agonists fail to alter release from cerebellar basket cells. J. Neurosci. 31, 16550-16555.

Represa, A., Tremblay, E., and BenAri, Y. (1987). Kainate binding sites in the hippocampal mossy fibers: localization and plasticity. Neuroscience 20, 739-748.

Rodriguez-Moreno, A., Kohl, M. M., Reeve, J. E., Eaton, T. R., Collins, H. A., Anderson, H. L., et al. (2012). Presynaptic induction and expression of timing-dependent long-term depression demonstrated by compartment-specific photorelease of a use-dependent NMDA receptor antagonist. J. Neurosci. 31, 8564-8569.

Rodriguez-Moreno, A., and Sihra, T. S. (2007). Metabotropic actions of kainate receptors in the CNS. J. Neurochem. 103, 2121-2135.

Ruiz, A., Campanac, E., Scott, R. S., Rusakov, D. A., and Kullmann, D. M. (2010). Presynaptic GABAA receptors enhance transmission and LTP induction at hippocampal mossy fiber synapses. Nat. Neurosci. 13, 431-438.

Ruiz, A., Fabian-Fine, R., Scott, R., Walker, M. C., Rusakov, D. A., and Kullmann, D. M. (2003). GABAA receptors at hippocampal mossy fibers. Neuron 39, 961-973.

Rusakov, D. A., and Kullmann, D. M. (1998). Extrasynaptic glutamate diffusion in the hippocampus: ultrastructural constraints, uptake, and receptor activation. J. Neurosci. 18, 3158-3170.

Safiulina, V. F., and Cherubini, E. (2009). At immature mossy fibersCA3 connections, activation of presynaptic $\mathrm{GABA}(\mathrm{B})$ receptors by endogenously released GABA contributes to synapses silencing. Front. Cell. Neurosi. 3:1. doi: 10.3389/neuro.03.001.2009

Salin, P. A., Scanziani, M., Malenka, R. C., and Nicoll, R. A. (1996). Distinct short-term plasticity at two excitatory synapses in the hippocampus. Proc. Natl. Acad. Sci. U.S.A. 93, 13304-13309.
Schmitz, D., Frerking, M., and Nicoll, R. A. (2000). Synaptic activation of presynaptic kainate receptors on hippocampal mossy fiber synapses. Neuron 27, 327-338.

Schmitz, D., Mellor, J., Breustedt, J., and Nicoll, R. A. (2003). Presynaptic kainate receptors impart an associative property to hippocampal mossy fiber long-term potentiation. Nat. Neurosci. 6, 1058-1063.

Schmitz, D., Mellor, J., and Nicoll, R. A. (2001). Presynaptic kainate receptor mediation of frequency facilitation at hippocampal mossy fiber synapses. Science 291, 1972-1976.

Scott, R., Lalic, T., Kullmann, D. M., Capogna, M., and Rusakov, D. A. (2008). Target-cell specificity of kainate autoreceptor and $\mathrm{Ca} 2+$-store-dependent short-term plasticity at hippocampal mossy fiber synapses. J. Neurosci. 28, 13139-13149.

Scott, R., and Rusakov, D. A. (2006). Main determinants of presynaptic $\mathrm{Ca} 2+$ dynamics at individual mossy fiber-CA3 pyramidal cell synapses. J. Neurosci. 26, 7071-7081.

Scott, R., and Rusakov, D. A. (2008). $\mathrm{Ca} 2+$ stores and use-dependent facilitation of presynaptic $\mathrm{Ca} 2+$ signaling. Proc. Natl. Acad. Sci. U.S.A. 105, E80. author reply E81.

Segev, I. (1990). Computer study of presynaptic inhibition controlling the spread of action potentials into axonal terminals. J. Neurophysiol. 63, 987-998.

Sherwood, J. L., Amici, M., Dargan, S. L., Culley, G. R., Fitzjohn, S. M., Jane, D. E., et al. (2012). Differences in kainate receptor involvement in hippocampal mossy fibre longterm potentiation depending on slice orientation. Neurochem. Int. 61, 482-489.

Siegel, S. J., Brose, N., Janssen, W. G., Gasic, G. P., Jahn, R., Heinemann, S. F., et al. (1994). Regional, cellular, and ultrastructural distribution of N-methyl-D-aspartate receptor subunit 1 in monkey hippocampus. Proc. Natl. Acad. Sci. U.S.A. 91, 564-568.

Singer, J. H., and Berger, A. J. (1999). Contribution of single-channel properties to the time course and amplitude variance of quantal glycine currents recorded in rat motoneurons. J. Neurophysiol. 81, 1608-1616.

Sjostrom, P. J., Turrigiano, G. G., and Nelson, S. B. (2003). Neocortical LTD via coincident activation of presynaptic NMDA and cannabinoid receptors. Neuron 39, 641-654.

Stell, B. M., Brickley, S. G., Tang, C. Y., Farrant, M., and Mody, I. (2003). Neuroactive steroids reduce neuronal excitability by selectively enhancing tonic inhibition mediated by delta subunitcontaining GABAA receptors. Proc. Natl. Acad. Sci. U.S.A. 100, 14439-14444.

Tachibana, M., and Kaneko, A. (1984). gamma-Aminobutyric acid acts at axon terminals of turtle photoreceptors: difference in sensitivity among cell types. Proc. Natl. Acad. Sci. U.S.A. 81, 7961-7964.

Takahashi, T., and Momiyama, A. (1991). Single-channel currents underlying glycinergic inhibitory postsynaptic responses in spinal neurons. Neuron 7, 965-969.

Trigo, F. F., Chat, M., and Marty, A. (2007). Enhancement of GABA release through endogenous activation of axonal GABA(A) receptors in juvenile cerebellum. J. Neurosci. 27, 12452-12463.

Turecek, R., and Trussell, L. O. (2001). Presynaptic glycine receptors enhance transmitter release at a mammalian central synapse. Nature 411, 587-590.

Turecek, R., and Trussell, L. O. (2002) Reciprocal developmental regulation of presynaptic ionotropic receptors. Proc. Natl. Acad. Sci. U.S.A. 99, 13884-13889.

Tyzio, R., Ivanov, A., Bernard, C., Holmes, G. L., Ben-Ari, Y., and Khazipov, R. (2003). Membrane potential of CA3 hippocampal pyramidal cells during postnatal development. J. Neurophysiol. 90, 2964-2972.

Verdier, D., Lund, J. P., and Kolta, A. (2003). GABAergic control of action potential propagation along axonal branches of mammalian sensory neurons. J. Neurosci. 23, 2002-2007.

Verheugen, J. A., Fricker, D., and Miles, R. (1999). Noninvasive measurements of the membrane potential and GABAergic action in hippocampal interneurons. J. Neurosci. 19, 2546-2555.

Vignes, M., and Collingridge, G. L. (1997). The synaptic activation of kainate receptors. Nature 388, 179-182.

Vogt, K. E., and Nicoll, R. A. (1999). Glutamate and gammaaminobutyric acid mediate a heterosynaptic depression at mossy fiber synapses in the hippocampus. Proc. Natl. Acad. Sci. U.S.A. 96, 1118-1122.

Wachowiak, M., and Cohen, L. B. (1999). Presynaptic inhibition of primary olfactory afferents mediated by different mechanisms in lobster and turtle. J. Neurosci. 19, 8808-8817.

Wall, P. D. (1958). Excitability changes in afferent fibre terminations and their relation to slow potentials. J. Physiol. 142, 1-21.

Wiebe, S. P., and Staubli, U. V. (1999). Dynamic filtering of recognition memory codes in the hippocampus. J. Neurosci. 19, 10562-10574.

Ye, J. H., Wang, F., Krnjevic, K., Wang, W., Xiong, Z. G., and Zhang, J. (2004). Presynaptic glycine receptors on GABAergic terminals facilitate discharge of dopaminergic neurons in ventral tegmental area. J. Neurosci. 24, 8961-8974.

Zhang, S. J., and Jackson, M. B. (1993). GABA-activated chloride channels in secretory nerve endings. Science 259, 531-534.

Zucker, R. S., Kullmann, D. M., and Bennett, M. (1998). "Release of neurotransmitters," in Fundamental Neuroscience, eds M. J. Zigmond, F. E. Bloom, S. C. Landis, J. L. Roberts, and L. R. Squire (London: Academic Press), 155-192.

Conflict of Interest Statement: The authors declare that the research was conducted in the absence of any commercial or financial relationships that could be construed as a potential conflict of interest.

Received: 15 October 2012; accepted: 10 December 2012; published online: 09 January 2013.

Citation: Ruiz AJ and Kullmann DM (2013) Ionotropic receptors at hippocampal mossy fibers: roles in axonal excitability, synaptic transmission, and plasticity. Front. Neural Circuits 6:112. doi: 10.3389/fncir.2012.00112

Copyright (c) 2013 Ruiz and Kullmann. This is an open-access article distributed under the terms of the Creative Commons Attribution License, which permits use, distribution and reproduction in other forums, provided the original authors and source are credited and subject to any copyright notices concerning any third-party graphics etc. 